students.narod.ru 2. Википедия с описаним SketchUp [Электронный pecypc] / Википедия. - Режим доступа: http://ru.wikipedia.org/ wiki/SketchUp. 3. Википедия с описанием Google Earth. [Электронный ресурс] / Википедия. - Режим доступа: http://ru.wikipedia.org/ wiki/GoogleEarth. 4. Моркун Н. В. Інформаційна багаторівнева система управління складними об'єктами / Моркун Н. В., Артюхов О. В. // Матеріали конференції «Сталий розвиток промисловості та суспільства». - Кривий Ріг, 2012. - Том 1. - С. 342-343.

УДК 378.147: 37.013 .42

I. I. Доброскок,

доктор пед. наук, професор, ДВНЗ «Переяслав-Хмельницький державний педагогічний університет імені Г. Сковороди»

\title{
РІВНІ ЕФЕКТИВНОСТІ ОРГАНІЗАЦЇ̈ НАВЧАЛЬНОЇ ДІЯЛЬНОСТІ МАЙБУТНІХ СОЦІАЛЬНИХ ПЕДАГОГІВ
}

У статті розкрито рівні ефективності організачї навчальної діяльності майбутніх соціальних педагогів. Охарактеризовано групи навчальних елементів, рівні сформованості знань відповідно до характеристики діяльності майбутніх фахівиів.

Ключові слова: рівні ефективності, організачія навчальної діяльності, сочіальні педагоги.

В статье раскрыты уровни эффективности организаиии учебной деятельности будуших сочиальных педагогов. Охарактеризованы группь учебных элементов, уровни сформированности знаний в соответствии с характеристикой деятельности будуших профессионалов.

Ключевые слова: уровни эффективности, организаџии учебной деятельности, сочиальные педагоги.

In the article the educational levels of the organization's effectiveness eyatelnosti future social workers. Characterized by a group of educational elements, the levels of formation of knowledge in accordance with the characteristics of future professionals.

Key words: levels of efficiency, organization of training activities and social workers.

Ініційований у межах трансєвропейського освітнього простору принцип неперервної освіти вимагає переосмислення теорії та практики організації навчальної діяльності майбутніх соціальних педагогів, оскільки набуває актуальності процес соціалізації всіх соціальних суб'єктів, а соціальнопедагогічний вплив визначається як процес цілеспрямованого 
створення оптимальних умов соціалізації індивіда, групи, суспільства, людства.

Окремі психолого-педагогічні аспекти навчальної діяльності майбутніх соціальних педагогів та її організації знаходимо в конструктивних розвідках Я. Бурлаки, Р. Вайноли, В. Загвязинського, А. Капської, О. Карпенко, 3. Фалинської, С. Харченка, С. Холостової.

Однак грунтовний аналіз наукових досліджень та емпіричних матеріалів засвідчує відсутність системного теоретикометодологічного й науково-технологічного забезпечення навчального процесу майбутніх соціальних педагогів. У контексті приєднання України до Болонського процесу організація навчальної діяльності майбутніх соціальних педагогів в умовах магістратури має чимало можливостей для розв'язання окреслених проблем. Окрім того, транснаціональна освіта, до якої інтенсивно долучається Україна, посилює європейський акцент оцінки й контролю якості освіти, що вимагає концептуально обгрунтованої цілісної педагогічної системи управління якістю професійної підготовки фахівців у ВНЗ.

Mета статmi - охарактеризувати рівні ефективності організації навчальної діяльності майбутніх соціальних педагогів.

Проблема структурування навчальних курсів тісно пов'язана 3 проблемою згортання інформації в логічні навчальні блоки і подання іiі в лаконічному вигляді, яка набуває актуальності в інформаційну добу. У галузі інженерії знань створюються різноманітні типи моделей подання знань у компактному, зручному для використання вигляді - логічні моделі, семантичні мережі, продукційні моделі тощо. Поряд 3 цим ефективні способи згортання знань описані у відомих психолого-педагогічних теоріях змістового узагальнення (В. Давидова Г41); формування системності знань (Л. Зоріної 「6]); програмованого навчання (В. Беспалька Г1; 2],

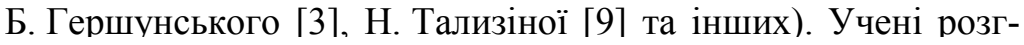
лядають моделювання в предметній, графічній і знаковій формах, структурні блок-схеми теми, логічні структури у вигляді деревоподібних класифікаційних схем, опорні конспекти тощо. Окреслені підходи є визначальними для формалізаціï процесу структурування навчальних курсів галузі знань «Соціальна педагогіка» залежно від обраного способу подання навчального матеріалу. 
Діагностування навчальних досягнень студентів під час формування навчальних курсів передбачає визначення критеріїв їх оцінювання у вигляді рівнів засвоєння:

1) упізнання об'єктів;

2) репродуктивні дії, що виконуються напам'ять, без будь-якої підказки;

3) продуктивна дія, що виконується для деякої множини об'єктів, що подібні до вже вивчених (конструюється суб' єктивно нова орієнтирна основа діяльності);

4) продуктивна дія, результатом якої є самостійне конструювання об'єктивно нової орієнтирної основи діяльносTi $[1]$.

3 позицій діяльнісного підходу, за способом використання засвоєної інформації, діяльність поділяють на репродуктивну i продуктивну [1]. Для репродуктивної діяльності властиві алгоритмічні дії (за точно описаними правилами) за відомих умов. Під час продуктивної діяльності студент створює нову по відношенню до отриманої (тієї, що викладалася на лекції, записана у підручнику тощо) орієнтирну основу дій.

За способами виконання як репродуктивна, так і продуктивна діяльність може бути виконаною за допомогою зовнішньої підказки (у явному або завуальованому вигляді) або без неї. Отже, кожен вид діяльності характеризується двома рівнями. Відповідність між видами діяльності, способами іiі виконання і рівнями засвоєння можна відтворити у вигляді таких взаємозалежностей: репродуктивна діяльність за допомогою підказки визначає рівень упізнання об' єктів; репродуктивна діяльність без підказки визначає рівень відтворення інформації; продуктивна діяльність за допомогою підказки визначає евристичний рівень засвоєння інформації; продуктивна діяльність без підказки визначає творчий рівень засвоєння інформації. Отже, сформованість заданого рівня діяльності співвідноситься із рівнем засвоєння навчальних елементів - засвоєної інформації.

Термінальні можливості людської психіки встановлюють за визначений час (наприклад, одне лекційне заняття, одне семінарсько-практичне заняття, одне лабораторно-практичне заняття тощо) певну кількість принципово нової для нього навчальної інформації, яку можна якісно сприйняти й усвідомити (на заданому рівні). Із цих міркувань, успішному розвязанню проблем упорядкування змістового блоку навчального курсу, розподілу його на окремі дози навчальної інфор- 
мації (змістові модулі), визначення дозованої послідовності видів навчальних занять під час вивчення певного змістового модуля сприятиме встановлення оптимального обсягу інформації.

Вимірювання обсягів інформації навчальних курсів потребує визначення окремих елементів його змістового блоку.

Під елементом змістового блоку навчальних курсів розуміють окремі знання або їх елементи (кроки, порції), які можуть по- різному «поєднувати» між собою, і пропонують вимірювати кількість навчального матеріалу в інформаційносмислових елементах тексту - завершених за змістом і формою простих суджень, подальший поділ яких втрачає сенс.

У роботах Л. Зоріної, $з$ позиції формування системності знань, «одиницею» змісту освіти визначається наукова теорія 「7, с. 211. У тезаурусній концепції елементом змістового блоку навчальних курсів визначено дескриптор - найбільш суттєве поняття у вигляді слів та словосполучень, вагомою характеристикою яких $\epsilon$ семантична стійкість та контрастність [8].

У своїх розвідках В. Беспалько у змістовому блоці навчальних предметів виокремлює навчальні елементи - об'єкти, явища, методи діяльності, обрані з науки і внесені до програми навчального предмета $\lceil 1$, с. 34]. Наведені твердження теоретично обгрунтовані в межах проведених досліджень, але визначення їх кількісних характеристик вимагає конкретизації, оскільки їм притаманна властивість кумулятивності (для описання однакового обсягу навчального матеріалу може бути використана різна кількість елементів знань).

Услід за В. Безпальком, ми називаємо окремий елемент змістового блоку навчальних курсів «навчальним елементом», який конкретизовано в нормативних документах вищої школи. Зокрема, навчальний елемент розглядається як певна дидактична одиниця - мінімальна доза навчальної інформації, що зберігає властивості навчального об'єкта Ґ2, с. 85-86].

У якості навчальних елементів визначаються поняття, явища, відношення, алгоритми. На наш погляд, використання цих типів навчальних елементів в якості окремих елементів змістового блоку навчального курсу $є$ доречним, тому що: дана термінологія використовується в нормативному й навчально-методичному забезпеченні підготовки фахівців 3 вищою освітою; для кожного елемента змістового блоку навчального курсу можна визначити його тип згідно з наведе- 
ним складом; такий поелементний розподіл змістового блоку навчального курсу дає можливість визначити обсяг навчального курсу; такий поелементний розподіл змістового блоку навчального курсу зручний для діагностичного завдання цілей навчання й побудови засобів діагностики рівнів засвоєння навчальних елементів.

Висновуємо, що елементами змістового блоку навчальних курсів галузі знань «Соціальна педагогіка» $є$ 「10; 11]:

- поняття - категорії, терміни, поняття, позначення (наприклад, «Форма соціально-педагогічної роботи - це ... (зовнішне виявлення способу організації діяльності соціального педагога і вихованця (вихованців))»; «Технології соціально-педагогічної роботи - це ... (сукупність способів, дій соціальних педагогів, спрямованих на встановлення, збереження чи поліпшення соціального функціонування об'єкта, сприяння саморозвиткові особистості, реалізації іiі творчого потенціалу, здібностей, задатків)»);

- явища - властивості, явища, факти, спостереження, твердження, опис об'єктів, механізмів тощо (наприклад, «До прикладних технологій соціально-педагогічної діяльності відносять технології соціального контролю, соціальної профілактики, соціальної терапії, соціальної корекції, рекламно-інформаційні тощо»);

- відношення - співвідношення, теореми, закони, концепиіï, правила, гіпотези, теорії, моделі (аналітичний або графічний опис процесу), залежності (зокрема аналітичні, графічні та логічні), структури тощо (наприклад, складовими компонентами технологізації $є$ структурний, функціональний, нормативний, операційний, інструментальний; ефективність соціально-педагогічної роботи залежить від визначення й усвідомлення таких закономірностей: (тенденцій життєдіяльності особи чи соціальної групи; особливостей їх соціального досвіду; влучності у постановці соціального діагнозу; добору адекватних шляхів розв'язання проблеми; визначення критеріїв і механізмів оцінки процесу та результатів соціально-педагогічної роботи));

- алгоритми - алгоритми діяльності (у тому числі алгоритми розв'язування задач, доведення теорем, рівнянь тощо), послідовності дій, прочедури, правила прийняття рішень, поведінки тошо (наприклад, алгоритм реалізації складників змісту соціально-педагогічних технологій: розмежування процесу на внутрішні етапи, фази; координація 
зусиль усіх підрозділів; визначення поетапності дій; визначення послідовності виконання всіх технологічних операцій; корекція дій залежно від змін у цьому процесі) $\lceil 5 ; 10 ; 11\rceil$.

Нормативні документи вищої освіти 「6] визначають групи навчальних елементів та їх зміст. Уважаємо за доцільне проілюструвати типи навчальних елементів змістового блоку навчальних курсів галузі знань «Соціальна педагогіка» (табл. 1).

Таблиия 1

\section{Групи навчальних елементів навчального курсу та їх зміст}

\begin{tabular}{|c|c|c|}
\hline Група & Зміст групи & $\begin{array}{c}\text { Приклад навчального елемента } \\
\text { галузі знань «Сочіальна педаго- } \\
\text { гіка» }\end{array}$ \\
\hline Поняття & $\begin{array}{l}\text { Поняття (категорії; терміни; поняття; позна- } \\
\text { чення) }\end{array}$ & $\begin{array}{l}\text { Сутність, специфіка, види, хара- } \\
\text { ктеристика технологій соціаль- } \\
\text { но-педагогічної роботи; поняття } \\
\text { «творчість» і «творча особис- } \\
\text { тість» в соціально-педагогічній } \\
\text { роботі }\end{array}$ \\
\hline Явища & $\begin{array}{l}\text { Явища (властивості; явища; факти; спосте- } \\
\text { реження; твердження; опис об'єктів; меха- } \\
\text { нізмів тощо) }\end{array}$ & $\begin{array}{l}\text { Етапи реалізації соціально- } \\
\text { педагогічних технологій; струк- } \\
\text { тура соціально-педагогічних } \\
\text { технологій }\end{array}$ \\
\hline $\begin{array}{l}\text { Відно- } \\
\text { шення }\end{array}$ & $\begin{array}{l}\text { Відношення (співвідношення; теореми; } \\
\text { закони; концепції; правила; гіпотези; теорії; } \\
\text { моделі (аналітичний або графічний опис } \\
\text { процесу); залежності, зокрема аналітичні, } \\
\text { графічні та логічні; структури тощо) }\end{array}$ & $\begin{array}{l}\text { Класифікація соціально- } \\
\text { педагогічних технологій; соціо- } \\
\text { культурні чинники соціалізації } \\
\text { суб'єкта й об'єкта соціально- } \\
\text { педагогічного процесу. }\end{array}$ \\
\hline $\begin{array}{l}\text { Алго- } \\
\text { ритми }\end{array}$ & $\begin{array}{l}\text { Алгоритми (алгоритми діяльності, у тому } \\
\text { числі алгоритми розв’язування задач, дове- } \\
\text { дення гіпотези тощо; послідовності дій; } \\
\text { процедури; правила прийняття рішень; } \\
\text { поведінки тощо) }\end{array}$ & $\begin{array}{l}\text { Стратегія і тактика інформацій- } \\
\text { ної діяльності соціального педа- } \\
\text { гога }\end{array}$ \\
\hline
\end{tabular}

Проілюстровані приклади доводять очевидність того, що рівні сформованості знань співвідносяться із характеристикою діяльності, яка дозволяє об' єктивно визначити ступінь їх сформованості (табл. 2).

Таблиия 2

Рівні сформованості знань відповідно до характеристики діяльності

\begin{tabular}{|l|l|}
\hline \multicolumn{1}{|c|}{ Рівень } & \multicolumn{1}{c|}{ Характеристика діяльності } \\
\hline Ознайомлювальний & $\begin{array}{l}\text { Студент має орієнтоване уявлення щодо понять, які вивчаються, здатен } \\
\text { відтворювати формулювання визначень, законів тощо, уміє розвәзувати } \\
\text { типові завдання шляхом підставлення чисельних даних. }\end{array}$ \\
\hline $\begin{array}{l}\text { Понятійно- } \\
\text { аналітичний }\end{array}$ & $\begin{array}{l}\text { Студент має чітке уявлення й поняття щодо навчального об'єкта, здатен } \\
\text { 3дійснювати смислове виділення, пояснення, аналіз, перенесення раніше } \\
\text { засвоєних знань на типові ситуації. }\end{array}$ \\
\hline
\end{tabular}




\begin{tabular}{|c|l|}
\hline \multicolumn{1}{|c|}{ Рівень } & \multicolumn{1}{|c|}{ Характеристика діяльності } \\
\hline $\begin{array}{l}\text { Продуктивно- } \\
\text { відтворювальний }\end{array}$ & $\begin{array}{l}\text { Студент має глибоке розуміння щодо навчального об'єкта, здатен } \\
\text { здійснювати синтез, генерувати нові уявлення, переносити раніше засвоєні } \\
\text { знання на нетипові, нестандартні ситуації. }\end{array}$ \\
\hline
\end{tabular}

Таблиця 3 репрезентує загальноприйняті позначення видів умінь та їх зміст, які проілюстровано прикладами 3 галузі знань «Соціальна педагогіка».

\section{Зміст умінь відповідно до виду вміння}

\begin{tabular}{|c|c|c|}
\hline Вид уміння & Зміст уміння & $\begin{array}{c}\text { Приклад навчального елемента з курсу } \\
\text { «ехнологї̈ сочіально- педагогічної } \\
\text { роботи» }\end{array}$ \\
\hline $\begin{array}{l}\text { Предметно- } \\
\text { практичне }\end{array}$ & $\begin{array}{l}\text { Уміння виконувати дії щодо пе- } \\
\text { реміщення об'єктів у просторі, зміну } \\
\text { його форми тощо. }\end{array}$ & $\begin{array}{l}\text { Уміння організації ігрових технік у } \\
\text { певних соціокультурних умовах. }\end{array}$ \\
\hline $\begin{array}{l}\text { Предметно- } \\
\text { розумове }\end{array}$ & $\begin{array}{l}\text { Уміння щодо виконання операцій з } \\
\text { розумовими образами предметів. Ці дії } \\
\text { вимагають наявність розвиненої систе- } \\
\text { ми уявлень і здатність до розумових дій } \\
\text { (наприклад, аналіз, класифікація, уза- } \\
\text { гальнення, порівняння тощо). }\end{array}$ & $\begin{array}{l}\text { Уміння обрати соціально- педагогічну } \\
\text { технологію і спосіб ії реалізації } \\
\text { (обгрунтування етапів, методів і засобів } \\
\text { соціально-педагогічної діяльності). }\end{array}$ \\
\hline $\begin{array}{l}\text { Знаково- } \\
\text { практичне } \\
\text { Вміння }\end{array}$ & $\begin{array}{l}\text { Уміння щодо виконання операцій зі } \\
\text { знаками та знаковими системами. При- } \\
\text { кладами цих дій є письмо, прокладання } \\
\text { курсу по карті, одержання інформації } \\
\text { від пристроїв тощо. }\end{array}$ & $\begin{array}{l}\text { Уміння здійснити статистично- } \\
\text { аналітичну обробку даних, отриманих } \\
\text { шляхом акетування, інтерв'ювання, } \\
\text { інформаційних соціальних програм. }\end{array}$ \\
\hline $\begin{array}{l}\text { Знаково- } \\
\text { розумове вмін- } \\
\text { ня }\end{array}$ & $\begin{array}{l}\text { Уміння щодо розумового виконан- } \\
\text { ня операцій зі знаками та знаковими } \\
\text { системами. }\end{array}$ & $\begin{array}{l}\text { Діï, що необхідні для виконання поета- } \\
\text { пних операцій соціально-педагогічних } \\
\text { технологій. }\end{array}$ \\
\hline
\end{tabular}

Рівні сформованості умінь і характеристика діяльності, яка дозволяє об' єктивно визначити ступінь їхньої сформованості, представлено в табл. 4.

Таблиия 4

Рівні сформованості умінь та характеристика діяльності, що їм властива

\begin{tabular}{|c|l|}
\hline $\begin{array}{c}\text { Позначення } \\
\text { рівня }\end{array}$ & \multicolumn{1}{|c|}{ Характеристика діяльності } \\
\hline I & $\begin{array}{l}\text { Уміння виконувати дію, спираючись на матеріальні носії інформації } \\
\text { щодо неї. }\end{array}$ \\
\hline II & $\begin{array}{l}\text { Уміння виконувати дію, спираючись на постійний розумовий кон- } \\
\text { троль без допомоги матеріальних носіїв інформації. }\end{array}$ \\
\hline III & Уміння виконувати дію автоматично, на рівні навички. \\
\hline
\end{tabular}

Однак із позицій діяльнісного підходу, як справедливо зазначають дослідники $[1 ; 2$ та ін.], не можуть окремо існувати знання й уміння. Знання й уміння становлять одну й ту саму 
діяльність, яка існує в різних формах (мовній, матеріальній, або предметній, розумовій або внутрішньомовній).

Отже, на основі цього положення, спираючись на рівні сформованості знань та умінь, виокремлені В. Беспальком, аналіз освітньо-кваліфікаційних характеристик випускників вищих навчальних закладів освіти за різними напрямами підготовки, власний досвід викладання у ВНЗ убачається за доцільне викоремлювати рівні засвоєння навчальних елементів певного навчального курсу галузі знань «Соціальна педагогіка», які у статті схарактеризовано і проілюстровано нами на прикладі галузі знань «Соціальна педагогіка».

У табл. 4 описано тільки три рівні засвоєння навчальних елементів. В. Беспалько виокремлює ще один рівень засвоєння - творчий, дослідницький, який передбачає самостійне конструювання об'єктивно нової орієнтирної основи діяльності. У процесі виконання діяльності такого рівня 3'являється об'єктивно нова інформація. До цього відноситься розв'язання науково-виробничих проблем, що потребують пошукової, дослідницької і винахідницької діяльності. До того ж, як зазначає В. Беспалько, про якість цієї діяльності може робити висновок лише група компетентних експертів [1].

Роль завдань 3 метою перевірки виконання діяльності такого типу виконують курсові та дипломні проекти (роботи), що передбачають прилюдний захист отриманих результатів та оцінювання їх спеціальною комісією. Звичайно, вивчення будь-якого навчального курсу повинно не виключати, а, навпаки, сприяти розвитку творчих умінь. Однак останні відносяться не до предметних умінь, а мають «надпредметний» характер, тому при визначенні рівнів засвоєння навчальних елементів нами не розглядаються. У нормативних документах вищої школи також визначено лише три рівні сформованості знань та умінь (табл. 4).

Удосконалення дидактичних засад формування навчальних курсів галузі «Соціальна педагогіка» передбачає дотримання принципів урахування міжпредметних зв'язків, доступності, варіативності, систематичності і дозованої послідовності у процесі формування змісту навчальних курсів, визначає способи упорядкування і наповнення змістового елементу навчального курсу в умовах магістратури.

Практичній реалізації принципу діагностування навчальних досягнень студентів сприятиме розв'язання задачі визна- 
чення завдань для кожного рівня засвоєння студентами навчальних елементів курсу: кожен наступний рівень засвоєння навчальних елементів включає попередній, що відповідає теорії поетапного формування розумових дій, яка розглядає процес засвоєння знань, умінь і навичок як послідовну зміну форм діяльності: від зовнішньої, матеріальної через внутрішньо мовленнєві дії до розумових дій, тобто засвоєння дії через формування іiі внутрішнього мовлення, коли дія швидко набуває автоматичного перебігу, стає недоступною для самоспостереження.

\section{Література}

1. Беспалько В. П. Основы теории педагогических систем: проблемы и методы психолого-педагогического обеспечения технических обучающих систем / Владимир Павлович Беспалько. Воронеж : Изд-во Воронеж. ун-та, 1977. - 304 с. 2. Беспалько В. П. Педагогика и прогрессивные технологии обучения В. П. Беспалько. - М. : Высшая школа, 1995. - 335 с. 3. Гершунский Б. С. Педагогическая прогностика: методология, теория, практика / Борис Семенович Гершунский. - К. : Вища школа. - 1986. - 200 с. 4. Давыдов В. В. Развивающее обучение / Василий Васильевич Давыдов. - М. : Педагогика, 1989. - 237 с. 5. Доброскок I. I. Короткий термінологічний словник із соціальної педагогіки, соціальної роботи / [уклад. І. І. Доброскок та ін.]. - Переяслав- Хмельницький : СКД, 2007. - 144 с. 6. Збірник законодавчих та нормативних документів про освіту. - Вип. 1. - К., 1991. 311 с. 7. Зорина Л. Я. Системность - качество знаний / Л. Я. Зорина. - М. : Знание, 1976. - 64 с. 8. Словарь-справочник по социальной работе / сост. Е. И. Холостова. - М. : Юристь, 1997. 424 с. 9. Талызина Н. Ф. Управление процессом усвоения знаний / Н. Ф. Талызина. - М. : МГУ, 1984. - 324 с. 10. Холостова Е. И. Глоссарий социальной работы / Е. И. Холостова. - M. : Издательско-торговая корпорация «Дашков и К», 2007. - 217 с. 11. Энциклопедия социальной работы : в 3 т. - Т. 3 / [пер. с англ.]. М. : Центр общечеловеческих ценностей, 1994. - С. 25-31. 